\title{
CONCEPTIONS AND PRACTICES OF PROFESSIONAL FAMILY HEALTH STRATEGY FOR HEALTH EDUCATION
}

\author{
Mayara de Melo Pereira ${ }^{1}$, Thiffany Pestana da Penha ${ }^{2}$, Elenice Maria Cecchetti Vaz ${ }^{3}$, Neusa Collet ${ }^{4}$, Altamira \\ Pereira da Silva Reichert ${ }^{5}$
}

\begin{abstract}
${ }^{1}$ Undergraduate Nursing Universidade Federal da Paraíba (UFPB). Paraíba, Brazil. Email: may_melo1520@hotmail.com
${ }^{2}$ Undergraduate Nursing UFPB. Paraíba, Brazil. E-mail: thiffanypestana@hotmail.com

${ }^{3}$ Master of Nursing. Assistant Professor, Department of Maternal-Child and Psychiatric Universidade Federal Fluminense (UFF), assigned as the Technical Collaboration UFPB. Paraíba, Brazil. E-mail: elececchetti@ig.com.br

${ }^{4}$ Ph.D. in Nursing. Assistant Professor, Department of Public Health Nursing and Psychiatric Center of Health Sciences and the Graduate Program in Nursing UFPB. Paraíba, Brazil. E-mail: neucollet@gmail.com

${ }^{5}$ Ph.D. in Child and Adolescent Health. Assistant Professor, Department of Public Health Nursing and Psychiatric Center of Health Sciences and the Graduate Program in Nursing UFPB. Paraíba, Brazil. E-mail: altareichert@gmail.com
\end{abstract}

\begin{abstract}
Qualitative research in order to identify the conceptions of health education that guide the practice of professionals working in the Family Health Strategy with families of children/adolescents with chronic disease. Data were collected from August to December 2011, through semi-structured interviews conducted with 21 professionals in two Integrated Family Health Units in João Pessoa-PB. Thematic analysis revealed that some professionals do the essence of health education activities and others do not develop targeted educational practice for this group, not recognizing children/adolescents with chronic illness in their coverage area. We emphasize the need for health professionals to adopt new ways of doing health and guided by dialogic relations that include health education.

DESCRIPTORS: Health education. Primary health care. Chronic disease. Child health.
\end{abstract}

\section{CONCEPÇÕES E PRÁTICAS DOS PROFISSIONAIS DA ESTRATÉGIA SAÚDE DA FAMÍLIA SOBRE EDUCAÇÃO EM SAÚDE}

\begin{abstract}
RESUMO: Pesquisa qualitativa, objetivando identificar as concepções de educação em saúde que norteiam a prática dos profissionais que atuam na Estratégia de Saúde da Família junto às famílias das crianças/adolescentes com doença crônica. Os dados foram coletados de agosto a dezembro de 2011, por meio de entrevista semiestruturada, realizada com 21 profissionais em duas Unidades Integradas de Saúde da Família de João Pessoa-PB. A análise temática evidenciou que alguns profissionais desconhecem a essência das atividades de educação em saúde e outros não desenvolvem prática educativa voltada para esse grupo, não reconhecendo crianças/adolescentes com doença crônica em sua área de abrangência. Salienta-se a necessidade de os profissionais de saúde adotarem novos modos de fazer saúde, pautados em relações dialógicas e que contemplem a educação em saúde.
\end{abstract}

DESCRITORES: Educação em saúde. Atenção primária à saúde. Doença crônica. Saúde da criança.

\section{CONCEPCIONES Y PRÁCTICAS DE LOS PROFESIONALES DE LA ESTRATEGIA SALUD DE LA FAMILIA SOBRE EDUCACIÓN EN SALUD}

RESUMEN: El trabajo se dio por medio de una investigación cualitativa que buscó identificar las concepciones de educación en salud que conducen la práctica de los profesionales que trabajan en la Estrategia de Salud de la Familia con el apoyo de las familias de los niños-adolescentes con enfermedad crónica. Los datos recolectados del mes de agosto a diciembre de 2011 se realizó a través de encuestas semiestructuradas, que contó con la participación de 21 profesionales de dos Unidades Integradas de Salud de la Familia de João Pessoa-PB. El análisis temático mostró que algunos profesionales desconocen la esencia de las actividades de educación en salud y otros no desarrollan práctica educativa que involucre ese grupo, y llega a desconocer niños-adolescentes con enfermedad crónica en el área en la cual abarca. Se observa que los profesionales de salud deben adoptar nuevos modelos de hacer salud, teniendo en cuenta la relaciones dialógicas que contemplen la educación en salud.

DESCRIPTORES: Educación en salud. Atención primaria a la salud. Enfermedad crónica. Salud de los niños. 


\section{INTRODUCTION}

Chronic conditions deserve special attention of health professionals who have the potential to cause stress and disruption in the individual patient and their family, especially if it is a child or adolescent. In childhood, chronic condition is defined as one that interferes with the functioning of the body of the child in the long term, and thus in the process of growth and development, limits their daily activities, affecting the daily lives of all family members, ${ }^{1}$ being necessary therefore, actions of health education to cope with this condition and improve their quality of life.

Health education should permeate all practices of child care and involve the family in the educational process, so that education departs from the reality experienced by the family, in a dialogic relationship ${ }^{2-3}$ with the professional, in which it presents itself with a genuine interest to hear each other.

In the care of children/adolescents with chronic disease process, health education is important to the achievement of independence, autonomy, acceptance and routine of their health management, thus it will be easier to prevent recurrences and prevent future hospitalizations. ${ }^{4}$

The model of health care to individuals with chronic diseases, focusing on biomedical dimension and gaze directed only to the disease, it is still a practice used, however, inefficient and nothing welcoming existing demands. For greater effectiveness of its actions, it is essential that clinical practice assume a dialogic, interactive and caring dimension. $^{5}$

The individual must be recognized in its social context and not the disease, aiming not only to the remission of symptoms, but the promotion of care that go beyond physical health. Thus, health education should be valued as an approach which is inherent to the social emancipation of improving the quality of individual and collective life process. ${ }^{6}$

Regarding chronic condition in childhood, the family can not be seen only as one who must fulfill certain actions by health professionals, but as an active subject in the construction and meaning of self-care process, enhancing dialogue and knowledge they hold the about the child's illness in order to promote accountability and active participation in the implementation of care and health improvements. ${ }^{6-7}$
Therefore, in addition to empowering families to effective care, it is necessary that this be marked in full, respect for life and citizenship, and that professionals know the specifics of families in order to organize their work process from the reality experienced by each child and their family. It is also urgent that the professional approach families of health services, generating new relationships and possibilities for dealing with grievances, as is the situation of chronic disease in childhood. ${ }^{8}$

Given these considerations, the study is justified by the need to investigate the thematic health education for families of children and adolescents with chronic illness in the Family Health Strategy (FHS). This is considered the first contact to the network of health care and should act as an effective and concrete service that prioritizes prevention and health promotion for all individuals, especially in childhood and youth. In this health care model, the professional should have a larger view of care, enhancing family presence and thinking health education with a view to preventing recurrence.

Besides the direct impact on the biological functions of the child/adolescent, chronic illness affects their existential dimension is necessary, therefore, that the professionals working in the FHS expand their actions, to promote support needed for children/adolescents and their families who experience chronic condition, in order to reorganize with the situation, production of skilled care, identification of social support and social networks, and building operations expanded as the diagnostic and therapeutic process, addressing the uniqueness of this group.

Therefore, the aim of this study was to identify the conceptions of health education that guide educational practice of professionals working in the Family Health Strategy with the family of the child/adolescent with chronic disease.

\section{METHODOLOGY}

Outlined a study was exploratory-descriptive study with a qualitative approach, conducted with professionals working in primary health care.

The fieldwork was conducted between August and December 2011, in two Integrated Family Health Units. Each unit contained four teams, belonging to one of the health districts of a city of Paraiba. This choice is due to the fact that the District be located in the area covered 
by the Federal University of Paraíba (UFPB), facilitating access to the research field because this field of practice of undergraduate courses that institution.

We opted for the integrated unit due to the ease of access to professionals who work there, considering that this unit has four full teams of the Family Health on a single physical space, corresponding to a total of 24 top-level professionals who hold distinct environments but also use some of the rooms in common, such as pharmacy, vaccination room, dressing room, reception, observation room, sample collection, misting room and cytological material sterilization room.

The study subjects were health professionals who attended top-level families of children/ adolescents enrolled in the Family Health Units (FHUs), elected for the study. Was used as inclusion criteria: be a doctor, nurse and dentist who attended to children or adolescents registered in the area covered by the Family Health Units; act in FHUs for a minimum period of six months, and, as exclusion criteria: medical, nurses and dentists who were on vacation or licensed during the period of data collection.

We opted for these occupational categories are part of the minimum top-level team of the FHS in the selected units. It is noteworthy that 21 professionals participated in the study because two refused to participate and one of the teams had no doctor. To ensure anonymity, identified the subjects with initial letter representing the professional category to which they belong, followed by the sequence number of the interview.

The empirical data collection was conducted through semi-structured interview, which was recorded and transcribed in full for analysis. The instrument for data collection was based on a script composed by the following guiding questions: what do you mean by health education? What educational practices that you develop with the families of children/adolescents with chronic illness? As you perform these activities?

Interviews were previously scheduled as convenience of the participants, except for those who chose to perform it right at the moment of first contact, in the health clinics. It is noteworthy that an interview was held at the home of the professional, because it stood on medical leave. All interviews were recorded on digital media, after approval of the interviewees in order to capture essential to the study of information.
The interpretation of the data followed the steps of the analysis temática: ${ }^{9}$ data organization, encompassing all the material collected with transcribed the interviews in order to perform a first organization of reports in a particular order, since starting a rating. After traced the horizontal map of the material and, subsequently, in the light of the objectives of this study, successive readings of the texts were performed by making an interrogative relationship with them to grasp the structures of relevance. This procedure allowed us to elaborate a classification by cross- reading. Then, from the structures of relevance, sued the reunification of the most relevant topics for the final analysis.

Having regard to Resolution n. 196/96 of the Ministry of Health, which regulates the conduct of research involving humans, this research project was approved by the Research Ethics Committee of the University Hospital Lauro Wanderley, whose opinion was favorable (Protocol n. 83/11). For all participants subject was presented the Statement of Consent, which contained the purpose of the research and its embodiment, so that they could nod his agreement, if they wanted to participate in this research as well as giving up his membership at any time research, ensuring their anonymity and confidentiality of information.

\section{RESULTS AND DISCUSSION}

The 21 expert participants in this study were female. The training time ranged from 15 to 30 among the nurses, a 40 years of medical and 21 between the three dentists. Of those interviewed, nine had a specialization in Family Health, Public Health six out four in Pediatrics, and only two had no professional specialization.

From the interpretation of the data, two empirical categories were constructed: Conceptions of professionals about health education; Educational practices and performed by professionals with families of children/adolescents with chronic disease.

\section{Conceptions of professionals about health education}

From the implementation of the Unified Health System (UHS) and the creation of the FHS, the guidelines focused on population health and how it should be passed, only to present another approach, leaving aside a biological vision for a magnified view of the individual. However, it is 
still common to encounter professionals whose actions remain focused on the biological model, and their activities in health education explanations revolve around just meant to control the disease. [...] is... the person clarify the type of disease and educate the patient to fight the disease type, clarify everything the person [...] clarify the disease, educate the [...] food, medicine, everything that proceeds with that kind of illness (E3); Then, health education is to make people in the community, users who we call, making them [...] have the idea to avoid, to the extent that they have both diseases, as well as complications of the diseases, they are also secondary prevention (M5); Education we develop thus guiding the patient, guiding how to do, giving tips on how [...] disease prevention is a health education importantly, the control of disease when these diseases are already installed, control them, the importance is to follow medical advice, as taking drugs, take medications correctly (M6).

In a study aiming ${ }^{10}$ to analyze the concepts of health education professionals of Family Health, also found that the biological model of illness was strongly present in educational activities developed by these professionals. Research ${ }^{11}$ has revealed that when the focus of attention becomes the pathology of the individual, the professional does not consider as active individuals in their health-disease process.

It is noticed in speeches that some professionals still view health education in a vertical manner, not considering the coming of popular knowledge knowledge. People, in general, so they do not have an education on health, [...] sometimes people are a bit harsh because they want to solve everything as they want [...], they want to know more than the professional (M3); Is the ability we have to transmit the knowledge for a person to let it transform your life, can do this transformation, get well-being [...] (E2).

The speeches above show the position of authoritative professional on the individual, making clear its vision of being the holder therefore know the power, while it is up to the user to abide by its guidelines and change of behavior, regardless of their knowledge of the best way to care for or even existing conditions for self-care.

This attitude is contrary to what is advocated for addressing individuals and collectivity in an extended care perspective. Being a social practice, health education should be based on the questioning of everyday life, in appreciation of the experience of individuals and social groups and reading about different realities. ${ }^{12}$
Despite the recognition of education as transformative practice of functioning, professional still retains a conception of content delivery, placing himself in a posture as being solely responsible for the healthier choices of the individual. In contrast, health education should be developed from the exchange of knowledge, since it favors space for reflection, with the seizure of new knowledge involving a change of attitude. ${ }^{13}$

However, unlike the understanding of health education as just imparting knowledge, advocated during past decades, this new design is guided by the idea that education in health aim to promote the autonomy of individuals from their own choices, so detached from the regulation and supervision of health professionals. ${ }^{14}$

With the change in the care model, the concept of health education emerged as of great importance in health promotion tool, making the care, both individual and collective, is an integral and humanized, as the following statements: our work is among other things, promote health, and how we promote health? Helping people more aware of health problems they have, helping them to be is preventing a lot of stuff, a lot of trouble, or when they have a problem they are dealing with it the best way possible. And so people, thus being able to make the best choice, right? To care for themselves and be better (E5); looks, health education, we constantly work promotion and disease prevention. So, we is not aimed at people like a sick person, and yes, a person can change the habits of life, in short, routine in order to have a life, better quality of life without being constantly coming to the clinic without being referred to a specialist center $(\mathrm{O} 4)$.

These statements are consistent with the literature,$^{15}$ since the concept of health education is anchored in the concept of health promotion, because both concepts require the participation of the population, their needs, their lifestyle, beliefs, values, desires, choices and experiences. Such participation requires involvement, commitment and solidarity, while daily construction decisions jointly established with all those involved in the educational process and remain committed to exchange experiences and knowledge.

To promote health education, you must know yourself, to be able to understand the other, to empathize, to exchange knowledge. Educating is a continuous process, in which we teach and learn every day, respecting the knowledge of others and learning from him. Thus, teaching is not 
transferring knowledge, is yes, create possibilities for its construction and production. ${ }^{16}$

\section{Educational practices carried out by professionals and the families of children/ adolescents with chronic disease}

Family Health as a strategic priority and substitutive model for the organization of primary care, is the gateway to the system and point of contact for preferential access to health services. ${ }^{17}$ This level of care are addressed common problems of the community and offered promotion, prevention, early diagnosis, treatment and rehabilitation services, referencing the more complex cases to other levels of care, incorporating and restating the principles of the UHS. ${ }^{18}$ Thus, professionals working in it should also take into account individuals with diseases already present, especially in relation to chronic diseases, with actions aimed at minimizing the pain and prevent complications of the disease.

Chronic illness in children/adolescents is characterized by causing repercussions that affect not only the patient but the whole family universe and can bring complex problems and long-term implications, which will translate into loss of quality of life of the entire group. Thus, chronic disease imposes changes in the life of the child/ adolescent and his family, who, amid the chaos, look for ways to adapt. This process depends on the complexity and severity of disease, the stage at which it is available and structures to meet the needs and regain balance. ${ }^{19}$

From this focus, some professionals reveal not develop a specific educational activity for this group, but state provide subsidies to families and children / adolescents who face this condition conversations with educational character: looks, has not taken a practice not have guidelines during home visits of changing positions, sanitization, is even more general guidelines, but has not so educational (M4); in fact we do not have anything specific [...] but we always accompanies that can we do home visits, makes some guidelines for the family, for family know because the disease, which is the disease, not just us trying to treat the disease, but the family needs to know the disease $[\ldots]$ (M5).

The members of the healthcare team must know the disease to orient and sensitize the binomial child/adolescent-family. Therefore, it is essential that professional values to quali- fied hearing, the process of expanding health because this skill awakens trust, establishing relationships between the multidisciplinary team/patients and families, thus allowing feelings of safety and satisfaction in this dialogical process. $^{20}$

The development of educational activities reported by professionals during the study consisted of individualized actions that occurred during home visits and checkups: good, this is always done in home visits, home visits, and these are... usually has patients with chronic diseases, bedridden patients, and then we make an education in that house, that family (O4); well as short time of my stay there is here, I have identified, is an only child, which is the $H$, he has a very serious problem in relation to the kidney, and then we have a pretty steady activity with him. Would therefore not an education in public health, obviously, because it has more cases, at least I know not, but thus supporting an education, to go to her house, she came here to take doubt she participate [...] (E7); directed not so, but we have children that have sickle cell anemia have a child with the disease celiac and has a diabetic so, it is not that framed for this thing, but during the nursing consultation we search the largest amount of information (E2); no. We do not talk so, isolated, do you understand? Single when we do child care, because the difficulty is great when we invite. Have also tried to form a group, they warn that this is better [...] (E5).

The statement revealed that some professionals are unaware of the potential that the home visit and childcare have to provide education to families of children/adolescents with chronic diseases, considering only those educational activities that are developed collectively.

A home visit is aimed at promoting health through an inter-relational and educational approach, developing individual and collective potential in fighting the disease. In this strategy, the client/family has the opportunity to broaden their understanding of their problem and reflect on the intervention of the reality in which he lives, focusing their autonomy. ${ }^{21}$

Have childcare effective by the regular and systematic monitoring of children to assess their growth and development, immunizations, guidance to mothers on accident prevention, breastfeeding, individual and environmental hygiene, and also for the early identification of health problems, with a view the effective and appropriate intervention. ${ }^{22}$ So it has strongly focused 
on promoting health through educational and preventive actions character.

You can see that the theoretical assumptions of the FHS and work context of team health favor the interaction with the family, and that activities such as home visits, data collection and time guidelines are timely situations so they can work family and develop educational activities recommended in this health model. However, it seems that there is a certain lack of preparation of health professionals to assist families, since the use of these activities are still marked by the traditional individual model of care, and dressing. ${ }^{23}$

This behavior may be related to the training of professionals participating in the study, since some of them have over 30 years of graduates, at the time when the school was facing the medical model of health centered and focus on the health education activities, as the individual was not seen as the protagonist of your health care.

Although practitioners claim to develop educational activities for families of children/ adolescents with chronic disease, we determined the reports that some of them do not perform any specific educational activity for this clientele, more than that, unaware in his area of children and scopes adolescents with chronic illness. No, not here, not so identify chronic disease, not (O1); Not with the disease itself, it does not (O3); No, no, [...] more specifically with the family that has a child with a disease chronic, we do not have (E1).

Among the individual stocks of health education, it is identified that a significant portion of the actions developed by professionals in FHUs is performed at the time people seek care in the health service, with the assistance based on the spontaneous demand of the population and reasoned almost exclusively in the biological, ${ }^{24}$ with little or no bond with the user.

A study ${ }^{25}$ aimed to identify the social network and the types of social support, evaluating supporters bonds from the perspective of families of children with chronic conditions in the Family Health Units of their coverage areas detected from the construction of the eco-map professionals FHUs not show sensitive to welcome the unique needs of these families, reflecting negatively on social network and support. Moreover, undertakes the construction of the line of care because there is no follow-up care of these children and families, proving that when the child needs health care, family search directly tertiary service.
This shows that there is still long way to go in this respect as at the time of hospital discharge, the child and family must be accompanied by professionals USFs, which should act concomitantly with hospital care to give adequate support to children, ${ }^{25}$ in order to avoid worsening of the problem and/or unnecessary hospitalizations.

This lack of connection between family and child/adolescent with chronic illness and the professionals who work in the FHS proves contrary to what is provided by the Ministry of Health, which prioritizes the Family Health as the main strategy for the reorganization of care Ladies, looking for the integration and organization of activities in a defined territory with the purpose of favoring face the problems identified. ${ }^{26}$

Noteworthy is perceived in some professionals to act as facilitators of health education activities difficult, highlighting the need for ongoing education, as this is a strategy that has the character of assigning scientific reality experienced by each professional knowledge in their daily lives, making become an important tool that should be used to meet the needs of family health teams. ${ }^{27}$

In order to equip health professionals, the Brazilian government established a National Policy of Permanent Education in Health (PEH) by GM Ordinance n. 198/2004, aiming at the transformation of professional practice and organization of work itself, taking as reference the health needs of populations and the organization of healthcare management. ${ }^{28-29}$ Currently, the challenges of building the SUS directly reflect the need to review the processes of training and organization of health work to promote a reorientation of care models and management practices and care.

In this context, improving the health of children/adolescents with chronic illness requires transformation of a system of health care that is still essentially fragmented, reactive and episodic, responding to the demands and conditions of acute events, focused on the disease to other system be proactive, integrated, continuous, focused on child/adolescent and family and focused on the promotion and maintenance of health. ${ }^{30}$

\section{CONCLUSIONS}

When dealing with health education, one should take into account that your main goal is the prevention of diseases and promotion of health, however, from this study, it was noticed that there are professionals who work in the FHS 
that do not have this conception, and eventually develop activities which they see as health education, however, focused on explanations just meant to control the disease.

This work enabled us to understand that in the context of the FHS, the activities carried out by professionals with the family and children/ adolescents with chronic disease demonstrate educational, for which use the strategy of household and/or childcare business. However, are based on individualized and specific guidelines therefore do not perform their activities in view of the comprehensive care.

It is noted that any contact made with the individual should be designed as a time to promote health, therefore, governed by health education. However, practitioners need to take ownership of these strategies in everyday practice, especially with the chronic condition in childhood given the constant demand of care in this population. It was found that there are professionals that refer not to develop any kind of educational practice focused on this nuclear family, often reaching unaware children/adolescents with chronic illness in their coverage area. Not because they do not exist, but because the weakness of the bond intersects the construction of larger, continuous and effective care to these families.

Some professionals combine health education only educational actions such lectures, workshops, group formation and rounds of conversation, ignoring the dialogical therapeutic encounter as an effective form of health education. In their everyday practice, the actions aimed at families and children/adolescents with chronic conditions are still poor, resulting in high demand for admissions with a diagnosis and/or relapse of chronic disease due to lack of proper management in primary health care.

Noting that the activities sometimes are not performed as recommended for primary health care, should raise other points that could contribute to this situation, as working conditions, consistent with the poor infrastructure of health facilities, bureaucracy and excessive activities in their daily lives. Also noteworthy is the influence that these professionals had in their academic progress, with a model that does not privileged actions of health education, becoming a pressing need to establish continuing education as a tool to promote skills of the labor process in the Strategy Family Health.
It is hoped that in so far as there is the identification of children/adolescents / families with chronic illness in the coverage areas of the studied units, considered avoidable hospitalization therefore sensitive to basic and treatable attention in this context, can be adopted educational strategies that articulate the various levels of health care, ensuring continuity of comprehensive care. Thus, it will be possible to reflect and (re) organize the work process in the care of this group and plan a service that meets your health needs.

Actions that give account of this universe of health care need to be linked also to policies that address children and adolescents with chronic disease because currently these show themselves invisible to both professionals as managers and policymakers at all levels of health attention, notably in primary care.

During this research it was established relevance in addressing this issue, as they were found a few articles that portrayed the theme about chronic disease in childhood and adolescence in the context of primary health care.

Thus, this study can contribute to health professionals and management agencies revise their conceptions and educational practices with families and children/adolescents with chronic disease to adopt new ways of doing health and rethink the ongoing in-service education to enable the construction of a look at health education, based on dialogical relations and appreciation of popular knowledge, and are guided by strengthening the capacity of choice of subjects and his leadership. More than that, you need to give visibility to the health problems of this population through expanded policies that address the unique needs of those who need health services for a long time, but for the rest of their lives.

\section{THANKS}

The National Council for Scientific and Technological Development (CNPq) for funding this research (Grant n. 475841/2010-7) and by the exchange of research productivity (Case $n$. 304374/2010-5).

\section{REFERENCE}

1. Nascimento LC, Rocha SMM, Hayes VH, Lima RAG. Children with cancer and their families. Rev Esc Enferm USP [online]. 2005 [access 2011 Nov 15]; 
39(4):469-74. Available in: http://www.scielo.br/ pdf/reeusp/v39n4/13.pdf

2. Góes FGB, Cava AMLA. The conception of health education of nurses in the care of hospitalized children. Rev Eletr Enferm [online]. 2009 Dec [access 2012 Feb 20]; 11(4):932-41. Available in: http:// www.fen.ufg.br/revista/v11/n4/pdf/v11n4a19. pdf

3. Ayres JRCM. Caution: work and interaction in health practices. Rio de Janeiro (RJ): Abrasco; 2009.

4. Leite SAO, Zanim LM, Granzotto PCD, Heupa S, Lamounier RN. Basic points of an education program for patients with type 1 Diabetes Mellitos. Arq Bras de Endocrinol Metab. 2008 May; 52(2):233-42.

5. Favareto CAO, Cabral CC. Narratives about the health-disease process: experiences in operative groups in health education. Interface Comunic Saúde Educ. 2009 Jan-Mar; 13(28):7-18.

6. Rodrigues D, Santos VE. Health education in the Family Health Strategy: a literature review of scientific publications in Brazil. J Health Sci Inst. 2010; 28(4):321-4.

7. Backs VMS, Lino MM, Prado ML, Reibnitz KS, Canaver BP. Competence of nurses in acting as health educators. Rev Bras Enferm. 2008 Nov-Dec; 61(6):858-65.

8. Vieira CS, Mello DF, Oliveira BRG, Furtado MCC. Networking and family social support following the newborn preterm and low birth weight. Rev Eletr Enferm [online]. 2010 Mar [access 2011 Nov 22]; 12(1):11-9. Available in: http://www.fen.ufg. $\mathrm{br} /$ revista/v12/n1/v12n1a02.htm

9. Minayo MCS. The challenge of knowledge: qualitative health research. 11 ed. São Paulo (SP): Hucitec-Abrasco; 2008.

10. Pinafo E, Nunes EFPA, González AD, Garanhani ML. Relationships between concepts and practices of health education in the vision of a team of family health. Trab Educ Saúde. 2011 Jul-Oct; 9(2):201-21.

11. Buss PM. An introduction to the concept of health promotion. In: Czeresnia D, organizer. Health promotion: concepts, thoughts, trends. 2 ed. Rio de Janeiro (RJ): Fiocruz; 2009. p.19-42.

12. Alves GG, Aerts D. Educational practices in healthcare and the Family Health Strategy. Ciênc Saúde Coletiva. 2011 Jan; 16(1):319-25.

13. Oliveira CB, Frechiani JM, Silva FM, Maciel ELN. The actions of health education for children and adolescents in the basic region of Maruípe in Vitória. Ciênc Saúde Coletiva. 2009 Mar-Apr; 14(2):635-44.

14. Colomé JS, Oliveira DLLC. Health education: by whom and for whom? The vision of graduate students in nursing. Texto Contexto Enferm. 2012 Jan-Mar; 21(1):177-84.

15. Santos RV, Penna CMM. Health education as a strategy for care to pregnant women, postpartum and newborn.Texto Contexto Enferm. 2009 Oct-Dec; 18(4):652-60.

16. Carvalho MF, Lira PIC, Romani SAM, Santos IS, Veras AACA, Filho MB. Monitoring of growth in children under one year: the situation in the health services in Pernambuco, Brazil. Cad Saude Publica. 2008 Mar; 24(3):675-85.

17. Giovanella L, Mendonça MHM, Almeida PF, Escorel S, Senna MCM, Fausto MCR et al. Family health: limits and possibilities for an integral approach to primary health care in Brazil. Ciênc Saúde Coletiva. 2009 May-Jun; 14(3):783-94.

18. Costa GD, Cotta RMM, Ferreira MLSM, Reis JR, Franceschini SCC. Family health challenges in the reorientation process of care model. Rev Bras Enferm. 2009 Jan-Feb; 62(1):113-8.

19. Holanda ER, Collet N. The difficulties of schooling of children with chronic disease in the hospital setting. Rev Esc Enferm USP [online]. 2011 Apr [access 2012 Oct 01]; 45(2):381-89. Available in: http://www. scielo.br/pdf/reeusp/v45n2/v45n2a11.pdf

20. Araújo YB, Collet N, Gomes IP, Amador DD. Knowledge and experiences of hospitalized adolescents with chronic disease. Rev Enferm UERJ. 2011 Apr-Jun; 19(2):274-9.

21. Torres HC, Roque C, Nunes C. Home visit: educational strategy for self-care of diabetic clients in primary care. Rev Enferm UERJ. 2011 Jan-Mar; 19(1):89-93.

22. Campos RM, Ribeiro CA, Silva CV, Saparolli ECL. Nursing consultation in child care: the experience of nurses in the Family Health Strategy. Rev Esc Enferm USP [online]. 2011 Jun [access 2012 Aug 14]; 45(3):566-74. Available in: http://www.scielo.br/ $\mathrm{pdf} /$ reeusp/v45n3/v45n3a03.pdf

23. Oliveira RG, MarconSS. Working with families in the Family Health Program: the nurse practice in Maringá-Paraná. Rev Esc Enferm USP [online]. 2007 Mar [access 2012 Jun 18]; 41(1):65-72. Available in: http:// www.scielo.br/pdf/reeusp/v41n1/v41n1a08.pdf

24. Roecker S, Marcon SS. Health education: accounts of the experiences of nurses with the Family Health Strategy. Invest Educ Enferm. 2011 Nov; 29(3):381-90.

25. Nóbrega VM, Collet N, Silva KL, Coutinho SED. Social network and support the families of children with chronic conditions. Rev Eletr Enferm. 2010 Sep [access 2012 Apr 30]; 12(3):431-40. Available in: http://www.revistas.ufg.br/index.php/fen/ article/view/7566/7859

26. Ministry of Health (BR). Surveillance, control and prevention of non-communicable chronic diseases: DCNT in the context of the Brazilian Unified Health. Brasília (DF): MS, Organização Pan-Americana da Saúde; 2005.

27. Rodrigues CC, Ribeiro KSQS. Health promotion: the design of a Professional Family Health Unit. Trab Educ Saúde. 2012 Jul-Oct; 10(2):235-55. 
28. Nespoli G, Ribeiro VMB. Speeches forming knowledge: an analysis of theoretical and methodological concepts that guide the educational material for training facilitators of continuing health education. Interface (Botucatu) [online]. 2011 [access 2013 Jul 03]; 15(39): 985-996. Available in: http:// www.scielo.br/pdf/icse/v15n39/aop2911.pdf

29. Ministry of Health (BR). Ordinance n. 198/GM/MS of February 13, 2004: National Policy on Continuing Education in Health and the Health System Strategy for training and development of employees in the sector and other measures. Brasília (DF): MS, 2004.

30. Mendes EV. The care of chronic conditions in primary care: the imperative of consolidation of the Family Health Strategy. Brasília (DF): Organização Pan-Americana da Saúde; 2012. 